\title{
Heritage as Action Research
}

\section{Guillermo Reher}

Citation: Reher, G. Heritage as Action Research. Sustainability 2022, 14, 282. https://doi.org/10.3390/ su14010282

Academic Editors: Ana Pastor Pérez, David Barreiro Martínez and Eva Parga Dans

Received: 24 November 2021 Accepted: 22 December 2021 Published: 28 December 2021

Publisher's Note: MDPI stays neutral with regard to jurisdictional claims in published maps and institutional affiliations.

Copyright: (c) 2021 by the author Licensee MDPI, Basel, Switzerland. This article is an open access article distributed under the terms and conditions of the Creative Commons Attribution (CC BY) license (https:// creativecommons.org/licenses/by/ $4.0 /)$.
Department of Education, Research Methods and Evaluation, Faculty of Humanities and Social Sciences, Comillas Pontifical University, 28108 Alcobendas, Spain; gsreher@comillas.edu

\begin{abstract}
This paper intends to weigh the importance of archaeology by how much impact it has, or could have, on society. Heritage values are precisely the language in which that impact translates to the general public. It is necessary, however, to balance the duty to protect heritage with the mutating and negotiated nature of these values. Archaeologists should not be seen as the wardens but rather as the enablers, the midwives, of local communities coming to terms with a deeper understanding of their past. The more effectively this heritage stimulates the relation of the community with these values, the greater the potential it will have to stimulate social innovation, which is the foundation for sustainable development or abandonment. For many the boon of cultural heritage is tourism, and this is true but to an insufficient extent. In order to be sustainable, tourism must be part of a broader social innovation strategy that foregoes easy pickings in favor of the creation of quality brands, employment, and the protection of traditional lifeways. Only in this way can heritage truly unlock a sustainable horizon.
\end{abstract}

Keywords: cultural heritage; landscape; knowledge transfer; sustainable development; social innovation; tourism; impact assessment

\section{Introduction}

The goal of this article is to prove that action research of cultural heritage is possible, but it requires a sharp, goal-oriented focus aiming at social innovation. This research is structured as a discourse where the conclusions are the logical outcomes of the previous steps. It considers existing research dialectically as a way of moving the ball forward. The paper aims to explore the theory behind many of the principles that deal with action research, archaeological practice, and cultural heritage but in a narrative flow. It, therefore, encompasses a theoretical exploration and the summation of various research outcomes, in order to arrive at conclusions that can stress the action-research potential of cultural heritage.

\section{Can Public Archaeology Be Considered Action Research?}

The principles of participatory action research (PAR), as outlined in Latin America during the Cold War, seek to use research to fix the problems of local communities primarily through education and social innovation [1]. According to Chevalier and Buckles, the three pillars of PAR are community participation, transformative action, and quality research [2]. The balance, however, seems to reveal enormous variation based on the theoretical and methodological approaches used [3]. In a way, this may also be reflected in the way public archaeology embodies PAR at times.

In theory, public archaeology reflects these principles in its theoretical underpinnings, if one is to follow the "European" understanding of the concept [4]. The practice, however, is often times too tilted in favor of public participation as a goal in itself [5]. This serves to upend the Gramscian concept of traditional intellectual activity as an endorsement of elite hegemony, but it hardly contributes to the transformative potential of PAR; the " $\mathrm{A}$ " stands for "action". 
Some would argue that the participation is, indeed, the action; that by participating in archaeological projects, social transformation is achieved [6]. This, however, is far from proven through sociocultural impact studies or the support of a theoretical framework. It is, therefore, little more than wishful thinking that volunteers in an excavation will be more sensitive to heritage values [7]. A side effect of this prioritization of participation above action is that the effective knowledge transfer of archaeology is fettered. Participatory archaeology becomes an end in itself, thereby, releasing the activity from any ulterior potential.

Participatory action research ultimately aims to solve the problems of society through science not to solve scientific problems with society. Notice the effect this has on the transfer of knowledge. In recent years, archaeology has been called upon to fulfill a much more fundamental role in helping contemporary society to tackle problems such as climate change and sustainable development [8]. In a way, the core of public archaeology has acknowledged as much through the Public Archaeology monographic issue Archaeology and Economic Development [9]. In it, the editors posit that archaeologists really do not understand the impact they have in society, not just economically speaking-which is their main concern-but also, I would argue, regarding the real social, cultural, and educational impact of their activity. This begs the following questions: What is archaeology for? What does it achieve in terms of action?

Don Henson wrote a chapter with the provocative title Does Archaeology Matter? in which he explored the actual use and impact of this activity [10]. He found that archaeology improved the quality of life in three ways, which are depicted in Figure 1.

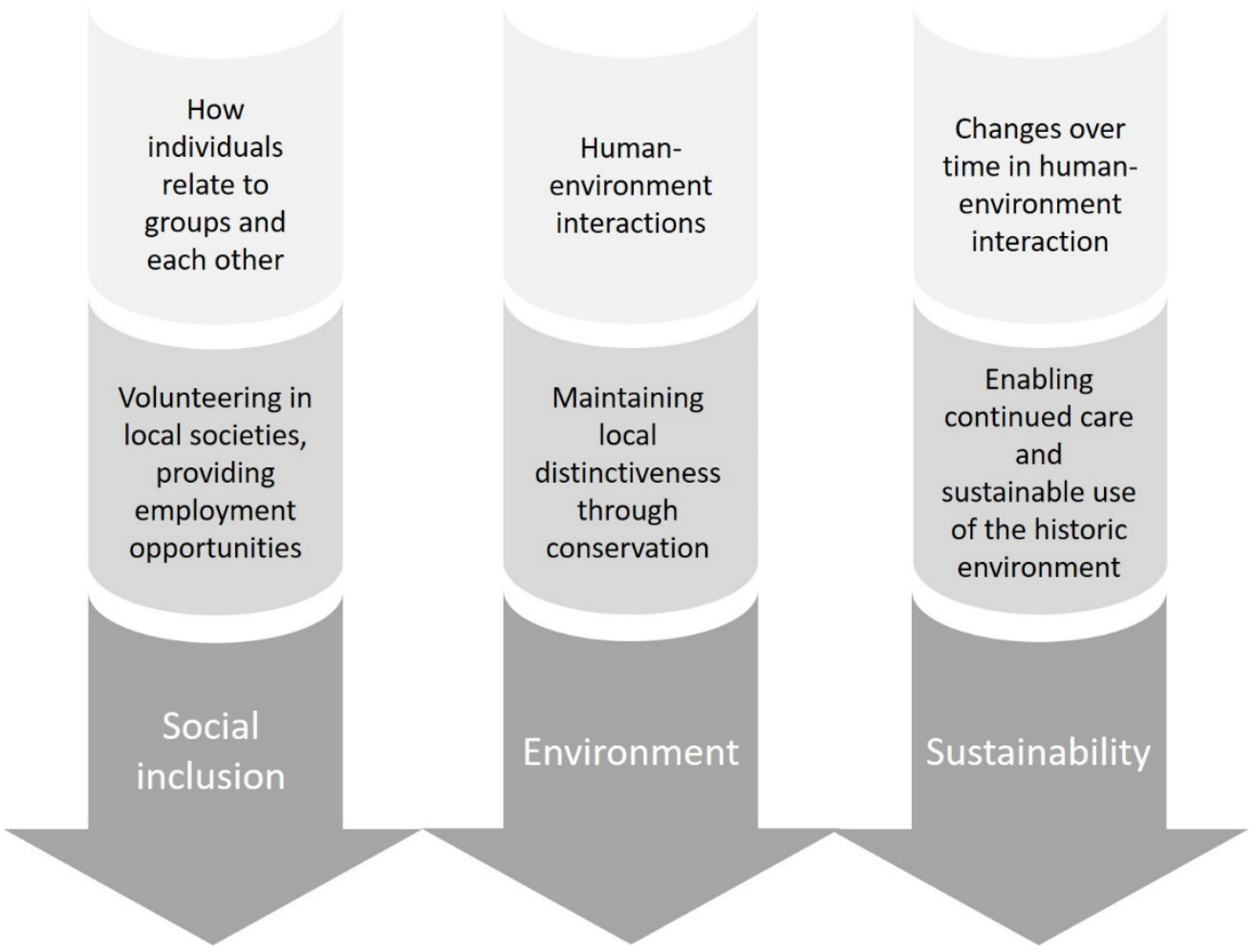

Figure 1. How archaeology can improve quality of life (derived from Table 1 in [10]).

Figure 1 helps conceptualize the quality of life-related benefits that archaeology provides according to Henson. A problem with public archaeology, as many understand it, is that the goals are not the arrows but rather the rows, representing the lack of objectiveminded follow-through that pervades many participatory projects.

The concept of "applied archaeology" helps bridge this gap by providing a more solid framework for what PAR really is when relating to archaeology [11,12]. It focuses more 
on the relation between archaeological knowledge and the use this knowledge has for society-the actual "action" that embodies knowledge transfer [13]. This had already been revealed as an area of contention by Smith:

Archaeological theory falls short in addressing heritage management and how archaeological knowledge is used within the management process. ([14] p. 300)

Nonetheless, it is precisely the use of the archaeology in the management of cultural heritage that causes friction in certain aspects. This begs a brief foray into the issues of conservation and management from an action-research perspective.

\section{Please Stay Off the Walls: Protection and Conservation}

The vision of cultural heritage as a museum cabinet, a display case for things to be seen in perfect conservation and extricated from their social and cultural context, has gone the way of landlines and Blu-ray discs. The inaugural issue of the Journal of Cultural Heritage Management and Sustainable Development contained an editorial that stated the conviction that the management of cultural heritage was one aspect that was inseparable from sustainable development [15].

Conservation is necessary, but cultural heritage must be intimately tied to the society and landscape it comes from. This principle has helped inform, and transform, the policy and scientific field of heritage management on the basis of the two Council of Europe Conventions, the European Landscape Convention [16] and the Convention on the Value of Cultural Heritage for Society (also known as the Faro Convention [17]). Both stress the democratic, accessible, and dynamic nature of cultural heritage as an integrated and integral part of sustainable development and societal well-being. This has resulted in far more dynamic models of heritage protection [18,19], often shifting the focus away from the site and the object to the landscape it is part of. Protecting heritages, and their landscapes, has become a possibility only inasmuch as local cultural values and development strategies were part of the picture [20]. This conservation-development dialectic has proved to be fraught in places where the drivers of change were more intent on transforming the landscape and, hence, the cultural values associated [21].

One of the greatest issues at stake is being able to convince society that protecting cultural heritage is worth it. This is problematic because the concept of "worth" is often tied to a very econometric perception, which can marginalize other forms of value-cultural, educational, or environmental, which may be just as important. Surprisingly, this is reflected in the very ecosystem services model that, although inclusive of non-monetary forms of value, actually fails to produce any models that can help balance the ledger with aspects that are not measured in dollars [22]. It has proved problematic to weigh in this debate with actual figures, due to the general lack of studies to demonstrate the impact of cultural heritage [23].

Some methodologies used for this purpose again fail to assess aspects that are not measured, and others simply disregard any categories that cannot be quantified [23]. An interesting attempt in recent years has been the work of Francesca Nocca [24]. The appearance of the sustainable development goals of Agenda 2030 warrants further impulse toward being able to measure how said goals are being achieved, thereby shaking up the ecosystem services structure [25].

The cultural values model, born out of the shortcomings that the ecosystem services model revealed, in particular with regard to landscape analysis, explicitly recognizes the impact that cannot be measured monetarily [26]. The great theoretical contribution is the acknowledgement that values can be either "surface" values, based on the practices, forms, and relationships of the present, or "embedded" ones, based on these very aspects but originating in previous phases. The past, hence, becomes embodied in the present values, and it is through ethnographic fieldwork that one can attempt to understand, and then measure, them [27].

Any attempt to protect specific elements in a landscape needs to comprehend this relation between the surface and embedded values, as well as the various cultural values 
that local communities bestow on the various forms, relations, and practices of said landscape. By drawing a polygon around it, and encasing it, you extricate it from the landscape, thus, removing it from the relations that give it meaning and underpin the surface and embedded values. It can become a display case, totally removed from the local community, at best, and seen as an alien inference and obstacle for development, at worst [28].

The issues discussed above demonstrate the problems associated with more traditional forms of conservation. Cultural heritage needs to be part of a sustainable development strategy, not an exception, not an exclusion, but a motor of said development. In order to achieve that, it is important to understand how it can relate with social innovation.

\section{Social Innovation ... With a Trowel?}

The Faro Convention [17] conceives the management of cultural heritage within the notion of 'Heritage Communities'. These are where various stakeholders could negotiate their differences and establish common strategies, which is a process often fraught with imbalances and power relations (see Figure 2) and corresponding sense of lack of empowerment, which is quite the opposite of the desirable outcome.

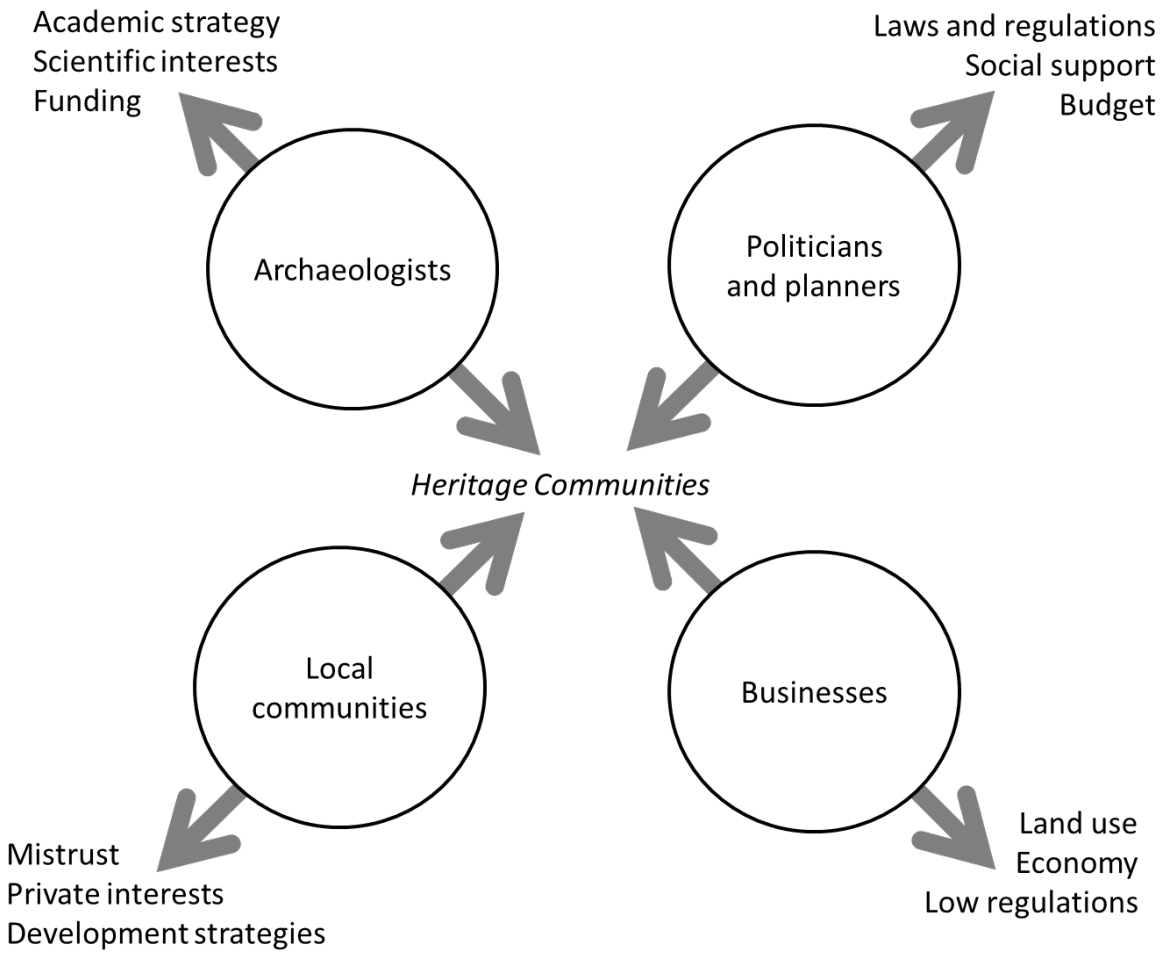

Figure 2. Conflicts of interest among stakeholders.

These problems can be offset either through top-down structuring and public consultation or else by establishing an alliance between archaeologists and local communities. This is best summarized in Figure 3, where the ideal process for implementing a cultural landscape reveals the need to start with a firm alliance-symbolized here as a marriage between the archaeologist and the local community, which then decides an academic and a management strategy, which is constantly shared with and participated in by the community. The result is a benefit for both said community, as well as society in general.

By initially stressing the need to establish an alliance between the expert and the local population, the initial mistrust is replaced with a strong bond that facilitates knowledge transfer, as has been pointed out by knowledge sociologists [29]. Figure 3 also reveals that, in the said process, the participation aspect of participation action research is also covered, and the action part is the implementation of the expert-driven strategy. The archaeologist is ideally positioned to carry this out due to the on-the-ground nature of his work, and the 
fact that it is surveying fieldwork that usually constitutes the first stage of local interaction with experts.

The nature of that first contact is key in determining the future relations. Distance and behaving as though no explanations were afforded, undermines the possible collaboration or mutual understanding that fosters an alliance. In a way, the archaeologist is the mediator between local communities and their cultural heritage, and this is a role that needs to be carried out. It is the archaeologist who has to deal with as well as shape the relation with planners, policy makers, and other stakeholders. Very much a superhero role, which only the archaeologist can do [10]. The specialist is laden with responsibilities for which they are, at best, only partially trained [12]. Moreover, little is to be won and much to be lost, if things go awry.

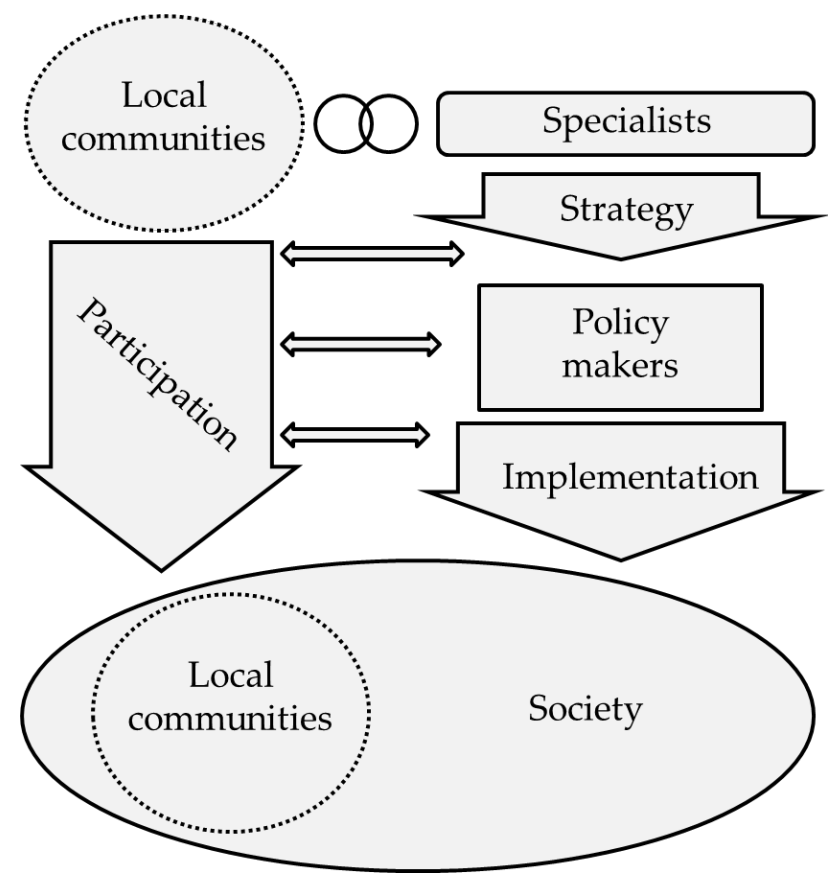

Figure 3. Ideal process for the implementation of a cultural landscape (based on [30]).

Public policy theory uses the concept of "boundary work" to understand the intersection between science and society, within a sociology of knowledge perspective [31]. It has earned much attention in The Netherlands, where the work of Robert Hoppe has revealed that it is inefficient for scientists to follow only scientific priorities, because research needs to have a social impact, which is why there is funding for it at all [32]. Unlike a significant portion of public archaeology, boundary work does not really question the scientific endeavors of the specialist but rather strives to answer the following questions: "What for?" and "How can it impact society more efficiently?". Action research locates science within society; not just as a mere process but rather as a system of innovation. Science does not advance on its own but as a social process that bears fruit that feed back into society [33].

Experimental social innovation has been defined by George Fairweather as follows:

... a new social subsystem whose methods include innovating models as alternative solutions to social problems, experimentally evaluating them, and disseminating the information to those who can make the appropriate changes. ([34] p. vi)

Social innovation steps beyond a linear perspective of innovation, which is exclusively found in private initiative, as stated by the Aho Report, which already acknowledged that an exclusively econometric perspective of social innovation left out very important types of innovation, e.g., technological, organizational, and service-related [35]. This dovetails neatly with the synchronous development of the notion of cultural heritage as an engine for social development [36]. Belfiore considers that the notion of assessing cultural heritage 
by measuring impact, rather than being rejected because of its econometric bias, should be embraced and changed so that it can reflect the true value [22]. Measuring the quality of life, or cultural and social benefits, cannot be limited to "number of resources per inhabitant", it goes far beyond that [37].

Being able to analyze the socioeconomic impact of cultural heritage in the landscape poses numerous challenges for the reasons seen above [23]. Most of the time, both policy makers and managers seek to facilitate local development through the promotion of tourism, as a sort of secret recipe for turning heritage into profit. This solution, however, has its problems.

\section{Souvenirs Are Not Trinkets, They Are Heritage Values}

The relation between archaeology and tourism is based on two basic principles [38]:

- The transfer of archaeological knowledge takes the form of cultural resources that the tourism sector capitalizes on.

- The archaeologist can help influence the shape of tourism in order to increase the benefits for the local community and ward off abuse-again reinforcing the ideal alliance referred to in the previous section.

Tourism is a significant stimulant of the local economy, favoring the creation or expansion of local businesses as long as they produce services and products that are synergetic with the cultural resources available. For instance, when a tourist visits a quaint fishing village, he is likely to impact not only souvenir shops, restaurants, bars, and hotels but also the consumption of fishing products, thereby, also positively affecting the local fishing industry. This is an example of a fair benefit that finds a more balanced distribution of profits by affecting much of the local economy and not just those businesses directly related with tourism.

Social innovation facilitates the creation and expansion of second-order service businesses that can be profitable due to the arrival of tourism [39]. In turn, it is also vital that these benefits affect a greater swath of the local economy. This is significant because, often, many of the values associated with a cultural landscape derive from land use, and often, tourism benefits hardly trickle over to those who curate the land [40].

In the case of urban heritage, much has been discussed regarding the possible gentrification effect of tourism. The enormous scope of challenges and strategies has ranged from modest successes, such as Bordeaux [41], to nightmarish scenarios that emerge when mass tourism runs rampant [42].

This is particularly challenging in rural communities and cultural landscapes, since many of the values associated with them are generated by local perception and farming activities that have created an indelible mark on the landscape [43]. The lack of economic incentive for local land use can result in the rewilding of a landscape and local abandonment, which results in the loss of those cultural values altogether [28].

Part of the problem stems from the lack of knowledge transfer of any type on behalf of archaeologists or cultural heritage managers. De-centering cultural heritage from the site or the object and re-assessing the relation with the landscape provides ample opportunity of the integration of the intangible heritage with the tangible. Traditions, food, and daily activities become the stuff of culture and are integrated into the tourism experience, much in the way of the fishing village example cited above. People eat fish because it is a fishing village, because of the traditions and activities associated with the sea, which then transfers directly into the culinary experience.

It is rare to find a rural landscape that does not have characteristic foodstuffs-local fish, particular legumes, seasonal vegetables, particularly breeds of cattle, honey, etc. Moreover, food is an excellent carrier of cultural values, as well as a source of nourishment for visitors. Turning the meal into a cultural experience benefits not only the restaurateurs but also the producers, who are the ones that curate the landscape. In a globalized market, local productions are often not competitive, begging the need for ways of adding extra value. Eco-friendly production, the maintenance of local breeds, and an association with 
local ways of preparing food all constitute an invaluable intangible heritage, which can, and should, be part of the experience and allow producers to turn a profit [44]. This sort of relation has been explored further in wine-producing countries, where the association between the territory and the foodie experience is strong [45-47].

An additional way in which farmers can benefit from tourism is by bringing back the original idea of rural tourism - integrated rural tourism [48] — whereby tourists live and work in a farm as a way of escaping the urban life and returning to a culturally and spiritually significant activity [49-53].

\section{Conclusions}

Cultural heritage research has extraordinary potential for stimulating social innovation, combining both economic development and sustainability. In order to fulfill this potential, however, it is important that heritage is conceived and managed as the knowledge output of archaeology within an action-research paradigm. Far from being scientifically self-serving, experts need to establish a strategy to maximize the impact and durability of cultural heritage, in order to benefit and empower local communities. This needs to be integrated within a broader sustainable development strategy that stresses entrepreneurship and social innovation associated with the cultural landscape. In this sense, measures to maintain and protect local traditional land use are practical strategies for the preservation of cultural values. These latter stages, rather than being alien to the original scientific activity of the archaeologist, need to be the final stages of the landscape strategy devised from the outcome of the project. In other words, once the archaeologist sets their eye in a landscape, they begin to create the future.

Funding: This research and the APC were funded by the Spanish Science and Innovation Ministry project "Economías locales, economía imperial: El occidente de la Península Ibérica (Siglos II A.C.- II D.C.) (LOKI)", grant number PID2019-104297GB-I00.

Institutional Review Board Statement: Not applicable.

Informed Consent Statement: Not applicable.

Data Availability Statement: Not applicable.

Acknowledgments: I am grateful for the support and guidance by Inés Sastre and Almudena Orejas (both CSIC) and Maria Cruz Cardete (UCM). I would also like to appreciate the support of the project "Registros ambiguos: comunidades locales y poblamiento indígena en los metalla publica del noroeste hispano (INDIGENAE)", grant number PID2020-114248GA-I00 of the Spanish Science and Innovation Ministry, directed by Brais Currás (CSIC).

Conflicts of Interest: The author declares no conflict of interest.

\section{References}

1. Brydon-Miller, M.; Maguire, P. Participatory action research: Contributions to the development of practitioner inquiry in education. Educ. Action Res. 2009, 17, 79-93. [CrossRef]

2. Chevalier, J.M.; Buckles, D.J. Participatory Action Research: Theory and Methods for Engaged Inquiry; Routledge: Abingdon-onThames, UK, 2013; p. 469.

3. Chambers, R. From PRA to PLA and Pluralism: Practice and Theory; Institute of Development Studies-IDS: Brighton, UK, 2007.

4. Schadla-Hall, T. Editorial: Public archaeology. Eur. J. Archaeol. 1999, 2, 147-158. [CrossRef]

5. Merriman, N. Public Archaeology; Merriman, N., Ed.; Routledge: London, UK, 2004.

6. Wylie, A. The integrity of narratives: Deliberative practice, pluralism, and multivocality. In Evaluating Multiple Narratives: Beyond Nationalist, Colonialist, Imperialist Archaeologies; Habu, J., Fawcett, C., Matsunaga, J.M., Eds.; Springer: New York, NY, USA, 2008; pp. 201-212.

7. Atalay, S.; Clauss, L.R.; McGuire, R.H.; Welch, J.R. Transforming archaeology. In Transforming Archaeology: Activist Practices and Prospects; Atalay, S., Clauss, L.R., McGuire, R.H., Welch, J.R., Eds.; Left Coast Press: Walnut Creek, CA, USA, 2014; pp. 7-28.

8. Atalay, S.; Clauss, L.R.; McGuire, R.H.; Welch, J.R. Transforming Archaeology: Activist Practices and Prospects; Atalay, S., Clauss, L.R., McGuire, R.H., Welch, J.R., Eds.; Left Coast Press: Walnut Creek, CA, USA, 2014; p. 266.

9. Gould, P.G.; Burtenshaw, P. Archaeology and economic development. Public Archaeol. 2014, 13, 3-9. [CrossRef] 
10. Henson, D. Does archaeology matter? In Community Archaeology. Themes, Methods and Practices; Moshenska, G., Dhanjal, S., Eds.; Oxbow Books: Oxford, UK, 2011; pp. 120-127.

11. Barreiro, D. La aureola perdida (Propuesta para una arqueología aplicada). ArqueoWeb 2006, 8, 301-306.

12. Chambers, E.J. Epilogue. Archaeology, heritage, and public endeavor. In Places in Mind: Public Archaeology as Applied Anthropology (Critical Perspectives in Identity, Memory, and the Built Environment); Shackel, P.A., Chambers, E.J., Eds.; Routledge: New York, NY, USA, 2004; pp. 193-208.

13. McDavid, C. From "traditional" archaeology to public archaeology to community action. The Levi Jordan Plantation Project. In Places in Mind: Public Archaeology as Applied Anthropology (Critical Perspectives in Identity, Memory, and the Built Environment); Shackel, P.A., Chambers, E.J., Eds.; Routledge: New York, NY, USA, 2004; pp. 35-56.

14. Smith, L. Heritage management as postprocessual archaeology? Antiquity 1994, 68, 300-309. [CrossRef]

15. Pereira Roders, A.; van Oers, R. Editorial: Bridging cultural heritage and sustainable development. J. Cult. Herit. Manag. Sustain. Dev. 2011, 1, 5-14. [CrossRef]

16. Council of Europe. The European Landscape Convention; Council of Europe: Faro, Portuga, 2000; Volume 176.

17. Council of Europe. Council of Europe Framework Convention on the Value of Cultural Heritage for Society; Council of Europe: Faro, Portugal, 2005; Volume 199.

18. Pérez Bustamante, L.; Parra Ponce, C. Paisajes culturales: El parque patrimonial como instrumento de revalorización y revitalización del territorio. Theoria 2004, 13, 9-24.

19. Sánchez-Palencia Ramos, F.J.; Ruiz del Árbol Moro, M. Los paisajes como patrimonio cultural: Geoarqueología, arqueología del paisaje y parques culturales. In Geoarqueología y Patrimonio en la Península Ibérica y el Entorno Mediterráneo; Santonja Gómez, M., Pérez González, A., Machado, M.J., Eds.; ADEMA: Soria, Spain, 2005; pp. 55-62.

20. King, T.F. Cultural heritage preservation and the legal system with specific reference to landscapes. In Landscapes Under Pressure. Theory and Practice of Cultural Heritage Research and Preservation; Lozny, L.R., Ed.; Springer: New York, NY, USA, 2006 ; pp. 243-254.

21. Lozny, L.R. Place, historical ecology and cultural landscape: New directions for applied archaeology. In Landscapes Under Pressure. Theory and Practice of Cultural Heritage Research and Preservation; Lozny, L.R., Ed.; Springer: New York, NY, USA, 2006; pp. 15-25.

22. Belfiore, E. 'Impact', 'value' and 'bad economics': Making sense of the problem of value in the arts and humanities. Arts Humanit. High. Educ. 2015, 14, 95-110. [CrossRef]

23. Reher, G.S. What is value? Impact assessment of cultural heritage. J. Cult. Herit. Manag. Sustain. Dev. 2020, 10, 429-436. [CrossRef]

24. Nocca, F. The role of cultural heritage in sustainable development: Multidimensional indicators as decision-making tool. Sustainability 2017, 9, 1882. [CrossRef]

25. Petti, L.; Trillo, C.; Makore, B.N. Cultural heritage and sustainable development targets: A possible harmonisation? Insights from the European perspective. Sustainability 2020, 12, 926. [CrossRef]

26. Stephenson, J. The cultural values model: An integrated approach to values in landscapes. Landsc. Urban Plan. 2008, 84, 127-139. [CrossRef]

27. Bieling, C.; Plieninger, T.; Pirker, H.; Vogl, C.R. Linkages between landscapes and human well-being: An empirical exploration with short interviews. Ecol. Econ. 2014, 105, 19-30. [CrossRef]

28. Reher, G. El turismo en el patrimonio arqueológico: Entre la "vitrinización” y la oportunidad perdida. Rev. Arqueol. Am. 2020, 38, 41-60. [CrossRef]

29. Alonso González, P. Between certainty and trust: Boundary-work and the construction of archaeological epistemic authority. Cult. Sociol. 2016, 10, 483-501. [CrossRef]

30. Orejas, A.; Reher, G.S. Historic landscapes, research and valorisation (a Spanish perspective). In Proceedings of the CHeriScape Conference II: Landscape as Heritage in Science, Amersfoort, The Netherlands, 5-6 November 2014; p. 12.

31. Gieryn, T.F. Boundary work and the demarcation of science from nonscience: Strains and interests in professional ideologies of scientists. Am. Sociol. Rev. 1983, 48, 781-795. [CrossRef]

32. Hoppe, R. Rethinking the science-policy nexus: From knowledge utilization and science technology studies to types of boundary arrangements. Poiesis Prax. 2005, 3, 199-215. [CrossRef]

33. Mansilla Castaño, A.M. El análisis del discurso arqueológico como metodología: Una primera aproximación. ArqueoWeb 1999, $1,19$.

34. Fairweather, G.W. Methods for Experimental Social Innovation; John Wiley and Sons: New York, NY, USA, 1967; p. 250.

35. Aho, E.; Cornu, J.; Gheorghiou, L.; Subirá, A. Creating an Innovative Europe. Report of the Independent Expert Group on RED and Innovation Appointed Following the Hampton Court Summit and Chaired by Mr. Esko Aho; European Commission: Luxembourg, 2006.

36. Barreiro, D.; Parga Dans, E. El valor económico del patrimonio cultural: Estrategias y medidas posibles para estimular la innovación social y los emprendimientos. In Proceedings of the Seminario Internacional “El Patrimonio Cultural: Un Aporte al Desarrollo Endógeno", Universidad Andina Simón Bolívar, Quito, Ecuador, 6-7 November 2013; p. 24.

37. Phillips, R.; Budruk, M. Introduction. In Quality-of-Life Community Indicators for Parks, Recreation and Tourism Management; Budruk, M., Phillips, R., Eds.; Social Indicators Research Series; Springer: London, UK, 2011; pp. 1-10.

38. Slick, K. Archaeology and the tourism train. In Public Benefits of Archaeology; Little, B.J., Ed.; University of Florida: Gainesville, FL, USA, 2002; pp. 219-227.

39. Manrique, R.; Viaggi, D.; Raggi, M. A Bayesian network highlighting the linkages between landscape structure and the local economy: The case of agritourism in lowland areas of Northern Italy. J. Environ. Plan. Manag. 2015, 58, 2137-2158. [CrossRef] 
40. Zavalloni, M.; Raggi, M.; Targetti, S.; Viaggi, D. Agricultural policies and the emergence of voluntary landscape enhancement efforts: An exploratory analysis of rural tourism using an agent-based model. J. Environ. Plan. Manag. 2015, 58, 2159-2175. [CrossRef]

41. Appendino, F. Balancing heritage conservation and sustainable development-The case of Bordeaux. IOP Conf. Ser. Mater. Sci. Eng. 2017, 245, 062002. [CrossRef]

42. Mikulić, J.; Vizek, M.; Stojčić, N.; Payne, J.E.; Časni, A.Č.; Barbić, T. The effect of tourism activity on housing affordability. Ann. Tour. Res. 2021, 90, 103264. [CrossRef]

43. Reher, G.S. Turismo sostenible en paisajes culturales: Frenando el abandono. In Nuevas Visiones en Educación y Empresa para una Nueva Sociedad; Ubierna, F., Ed.; Fragua: Madrid, Spain, 2019; pp. 367-385.

44. Pugliese, P. Organic farming and sustainable rural development: A multifaceted and promising convergence. Sociol. Rural. 2001, 41, 112-130. [CrossRef]

45. Tempesta, T.; Giancristofaro, R.A.; Corain, L.; Salmaso, L.; Tomasi, D.; Boatto, V. The importance of landscape in wine quality perception: An integrated approach using choice-based conjoint analysis and combination-based permutation tests. Food Qual. Prefer. 2010, 21, 827-836. [CrossRef]

46. Tassinari, P.; Torreggiani, D.; Benni, S.; Dall'Ara, E. Landscape quality in farmyard design: An approach for Italian wine farms. Landsc. Res. 2013, 38, 729-749. [CrossRef]

47. Nikolov, D.; Borisov, P.; Radev, T. Integrated landscape analysis: Consumer's preferences approach for defining the competitive landscape composition. A case of wine tourizm in Pazardjik district, Bulgaria. Bulg. J. Agric. Sci. 2014, 20, 761-766.

48. Saxena, G.; Clark, G.; Oliver, T.; Ilbery, B. Conceptualizing integrated rural tourism. Tour. Geogr. 2007, 9, 347-370. [CrossRef]

49. Balestrieri, G. Il Turismo Rurales Nello Sviluppo Territoriale Integrato Della Toscana; IRPET (Istituto Regionales Programmazione Economica Toscana): Regione Toscana, Italy, 2005.

50. Belletti, G. Ruralità e turismo. Ariregionieuropa 2010, 6, 20.

51. Cawley, M.; Gillmor, D.A. Integrated rural tourism: Concepts and practice. Ann. Tour. Res. 2008, 35, 316-337. [CrossRef]

52. Panyik, E.; Costa, C.; Rátz, T. Implementing integrated rural tourism: An event-based approach. Tour. Manag. 2011, 32, 1352-1363. [CrossRef]

53. Cawley, M.; Marsat, J.-B.; Gillmor, D.A. Promoting integrated rural tourism: Comparative perspectives on institutional networking in France and Ireland. Tour. Geogr. 2007, 9, 405-420. [CrossRef] 